University of Nebraska - Lincoln

DigitalCommons@University of Nebraska - Lincoln

USDA National Wildlife Research Center - Staff Publications
U.S. Department of Agriculture: Animal and Plant Health Inspection Service

2013

\title{
Graphically Characterizing the Movement of a Rabid Striped Skunk Epizootic Across the Landscape in Northwestern Wyoming
}

\author{
Craig A. Ramey \\ USDA/APHIS/WS National Wildlife Research Center \\ Kenneth W. Mills \\ University of Wyoming \\ Justin W. Fischer \\ USDA/APHIS/WS National Wildlife Research Center, Justin.w.fischer@aphis.usda.gov \\ Robert G. McLean \\ National Wildlife Research Center \\ Kathleen A. Fagerstone \\ National Wildlife Research Center
}

See next page for additional authors

Follow this and additional works at: https://digitalcommons.unl.edu/icwdm_usdanwrc

Part of the Life Sciences Commons

Ramey, Craig A.; Mills, Kenneth W.; Fischer, Justin W.; McLean, Robert G.; Fagerstone, Kathleen A.; and Engeman, Richard M., "Graphically Characterizing the Movement of a Rabid Striped Skunk Epizootic Across the Landscape in Northwestern Wyoming" (2013). USDA National Wildlife Research Center - Staff Publications. 1553.

https://digitalcommons.unl.edu/icwdm_usdanwrc/1553

This Article is brought to you for free and open access by the U.S. Department of Agriculture: Animal and Plant Health Inspection Service at DigitalCommons@University of Nebraska - Lincoln. It has been accepted for inclusion in USDA National Wildlife Research Center - Staff Publications by an authorized administrator of DigitalCommons@University of Nebraska - Lincoln. 


\section{Authors}

Craig A. Ramey, Kenneth W. Mills, Justin W. Fischer, Robert G. McLean, Kathleen A. Fagerstone, and Richard M. Engeman 


\title{
Graphically Characterizing the Movement of a Rabid Striped Skunk Epizootic Across the Landscape in Northwestern Wyoming
}

\author{
Craig A. Ramey, ${ }^{1}$ Kenneth W. Mills, ${ }^{2}$ Justin W. Fischer, ${ }^{1}$ Robert G. McLean, ${ }^{1}$ \\ Kathleen A. Fagerstone, ${ }^{1}$ and Richard M. Engeman ${ }^{1}$ \\ ${ }^{1}$ National Wildife Research Center, 4101 LaPorte Ave., Fort Collins, CO 80521 \\ ${ }^{2}$ University of Wyoming, Laramie, WY
}

\begin{abstract}
A striped skunk (Mephitis mephitis) rabies epizootic in northwestern Wyoming was studied from the Index Case in 1988 to the last case in 1993, and possibly is the first rabies epizootic in a previously rabies-free zone monitored from beginning to end. The $843 \mathrm{~km}^{2}$ study area comprised skunk habitat along $90 \mathrm{~km}$ of Shoshone River's floodplain from Bighorn Lake upstream to Cody. Of 1,015 skunks tested, 215 were rabiespositive. Integrating spatial and temporal data from positive cases, we analyzed the epizootic's movements and dynamics at 6-month intervals using multivariate movement maps, a new multivariate descriptive methodology presented here to demonstrate the epizootic's directional flow, while illustrating areas with higher case densities (i.e., wave crests). This approach should help epidemiologists and public health officials to better understand future rabies epizootics.
\end{abstract}

Keywords: epizootic movements, Mephitis mephitis, multivariate movement maps, Shoshone River Basin

\section{INTRODUCTION}

Rabies is usually transmitted by the bite from an infected mammal (Sikes 1981), and is among the oldest known acute infectious viral diseases of the central nervous system with reports by Aristotle and Hippocrates circa 400 BC (Baer 1975). Rabies has a widespread global distribution (Rupprecht et al. 1995) and has been reported in North America since circa 1800 (Parker 1975). The primary rabies reservoir in the U.S. changed from domesticated dogs (Canis familiaris) and cats (Felis catus) to striped skunks (Mephitis mephitis) in 1960 (McLean 1970), then to rac-

Published online: June 29, 2013

Correspondence to: Richard M. Engeman, e-mail: Richard.m.engeman@aphis. usda.gov coons (Procyon lotor) in 1989, with striped skunks remaining the primary rabies reservoir on the Great Plains. Rabies is nationally important due to public health, agricultural, and economic issues (Sikes 1981; Hanlon et al. 1999; Shwiff et al. 2007).

In Wyoming, rabid skunks have been reported on the High Plains east of the Rocky Mountains since 1938 (Thorne and McLean 1982), but northwestern Wyoming where the Shoshone River Basin (SRB) is located had no previous reports of skunk rabies (Centers for Disease Control 1985). On 15 August 1988, the first documented case of striped skunk rabies, the Index Case (IC), was recorded near the joining of Polecat and Sage Creeks east of Deaver (Ramey et al. 2007). In response, the Bighorn County Predator Board (BCPB) provided a trapper for 
rabies surveillance in January 1989. Surveillance and depopulation initiatives were assumed in 1990 by U.S. Department of Agriculture/Wildlife Services (WS), the Federal agency with responsibility for managing conflicts with wildlife (U.S. Department of Agriculture/Animal and Plant Health Inspection Service et al. 1997). Of various depopulation methods (i.e., poisons, shooting, and trapping) employed in other outbreaks, mainly live trapping was used in the SRB to allow release of non-target dogs and cats with proof of current rabies vaccinations. An aggressive domestic animal vaccination program was initiated by local veterinarians.

Rabies epizootics in wildlife have been reported to expand geographically in a wave-like front (e.g., Rosatte et al. 1986; Winkler 1975) and various models of spatial spread have been developed in this specialized field (Kallen et al. 1985; Jeltsch et al. 1997). The models are generally based on empirical reports of epizootic waves occurring in various vectors including fox (Macdonald and Voigt 1985) and raccoons (Centers for Disease Control 1985; Smith et al. 2002). Temporal and spatial data were accumulated as skunk rabies cases were detected. Using these data, we developed and applied a novel graphical construct for conceptually presenting the dynamics of the epizootic analogous to wave-like fronts. This method should help epidemiologists and public health officials better understand and manage future rabies epizootics.

\section{MetHOdS}

\section{Study Area}

The Shoshone River flows $180 \mathrm{~km}$ eastward from Yellowstone National Park to Bighorn Lake. Its geomorphic evolution demonstrates erosion terracing above the floodplain forming gravel benches (Ritter 1975). Our floodplain study area included the lower SRB between Buffalo Bill Reservoir west of Cody downstream to Bighorn Lake and Canyon (Fig. 1; Ramey et al. 2008). Besides Cody, it included the towns of Powell, Byron, and Lovell, and its primary tributary Sage Creek includes the northern towns of Frannie, Deaver, and Cowley. The Shoshone River meanders through the study area with an average descent of $5.1 \mathrm{~m} / \mathrm{km}$. The floodplain is composed of riparian areas with irrigated crops and pastures. The primary skunk habitat in the general $843 \mathrm{~km}^{2}$ study area (Bonner 2002) included riparian areas along the Shoshone River dominated by deciduous trees or tall shrubs $\left(109 \mathrm{~km}^{2}\right)$, while the secondary habitat $\left(734 \mathrm{~km}^{2}\right)$ included irrigated agricultural

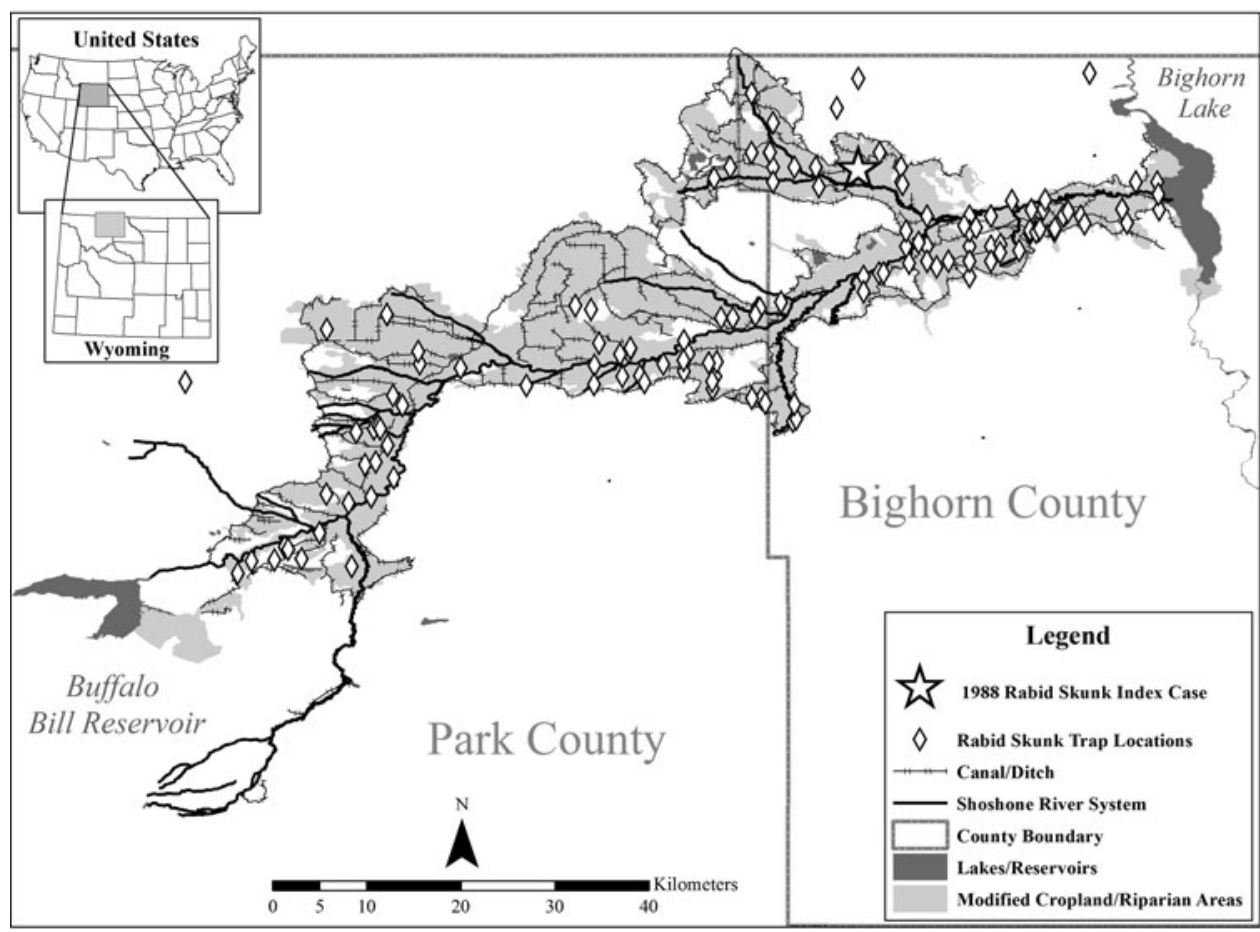

Figure 1. The lower SRB study area of northwestern Wyoming during the 1988-1993 striped skunk rabies epizootic, identifying its major tributaries, canals, general skunk habitat, and all rabid striped skunk capture locations (diamonds) including the Index Case (star). 
land maintained by an extensive canal system up to 100 years old (Fig. 1; Ramey et al. 2010).

\section{Rabid Skunk Capture and Documentation}

Trapping around the IC commenced in February 1989, but only in skunk habitat confirmed by skunk tracks and other signs. Once an epizootic was identified as in progress in late spring 1989, trapping was conducted throughout the SRB. To most efficiently apply limited resources, trapping effort was focused on areas where rabies cases had been confirmed, where citizens had reported animals with suspicious behavior, and in skunk habitat types also showing skunk sign. Sixty to 100 traps were used through the study, mostly single door live traps baited with sardines. Trapping was conducted all months of the year when snowfall did not prevent accessibility, i.e., from February to November. A small proportion of skunks were taken with coyote gas cartridges (Ramey 1992), kill traps, and shooting.

Each captured animal had its capture location and date documented in trapper logs and on carcass tags. All skunks were brought to a SRB veterinarian who initiated an Incident Case form before submitting it to WSVL. All specimens received by WSVL were assigned a unique accession number. Information recorded included: species, date received, landowner's or lease holder's name, veterinarian's name, overall owner/responsible party (e.g., generally the Wyoming Department of Agriculture), county, state, and identification number used by the trapper.

\section{Rabies Testing}

All specimens were diagnosed at Wyoming State Veterinary Lab (WSVL) using the fluorescent antibody (FA) test (recently renamed the direct fluorescent antibody (dFA) test), which involved microscopic examination of brain tissue (Dean and Abelseth 1973; McQueen et al. 1960). The confirmation test used hippocampus impression smears prepared on glass slides and air-dried. Slides were placed in acetone at $-20^{\circ} \mathrm{C}$ for $30 \mathrm{~min}$. After fixation, slides were airdried at room temperature and the impression was circled with a wax pen. A previously determined dilution of polyclonal fluorescein isothiocyanate-labeled antirabies conjugate (BBL Microbiology Systems, Cockeysville, MD) was placed on the impression. Then slides were incubated in a humidor at $37^{\circ} \mathrm{C}$ for $30 \mathrm{~min}$, washed three times in phosphate buffer ( $\mathrm{pH}$ 7.2), and cover slips were placed using FA mounting fluid. The slides were immediately evaluated on a FA microscope for rabies antigens.

\section{Location Data}

Locations for five rabid skunks taken using coyote gas cartridges (Cloudwalker 1991) were determined using GPS technology (Ramey et al. 2007). For live-trapped rabid skunks, locations were obtained from the trapper's logs and BLM maps and subsequently refined using GIS maps. Alternatively, whenever the trapper's logs were incomplete, geocoded locations for the central point of the cooperators' land holdings, or specific field if known, were used to estimate the capture location. About $90 \%$ of the rabid skunk locations were recorded with four identifiers: name of the land owner or lease holder, their address, the rabid skunk's location using township and range system information and GPS coordinates.

\section{Multivariate Movement Maps}

Our graphical construct was conceptually based on fluid wave dynamics to characterize the leading edge and crest through SRB's spreading skunk rabies epizootic (Ramey et al. 2011). The leading edge describes the furthest rabid outlier(s) from the IC at any particular time. The wave's crest(s) demonstrates area(s) with higher frequencies of rabies cases. Both dynamic constructs can assist understanding the spreading epizootic, while also providing concepts for communicating with trapper(s), cooperators, and the public.

Multivariate movement maps (MMMs) were developed to effectively integrate multivariate time series displays with spatial dimensions, advancing concepts of quantitative graphics (Tufte 1983). Our use illustrates: (1) spatial and temporal locations of rabies cases, (2) positive outliers in the leading edge of the disease front, (3) higher densities of cases in the crest, and (4) the directional flow of the spreading epizootic. MMMs could be depicted using any date range, and we selected 6-month illustrations because biannual time frames insured sufficient observations to create practical maps, while also capturing the epizootic's advances as the animals entered their winter denning period and then also as young dispersed during the summer.

MMMs created a new line GIS data layer indicating rabies frequencies within short river baseline segments 
between Buffalo Bill Reservoir and Bighorn Lake primarily, and between Sage Creek from the Montana state line to its confluence with the Shoshone River secondarily. These 2 baselines were divided into $2.5-\mathrm{km}$-long segments. All rabid skunk locations within $180^{\circ}$ perpendiculars of each $2.5 \mathrm{~km}$ segment were summed into 6-month increments during the epizootic. The number of rabies cases for each segment converted to a corresponding line thickness. Our baseline ArcGIS 9.2 symbology line thickness was 1.5. This line's thickness was altered by a factor of 5 for each rabid skunk case within the segment (e. g., 2 rabid skunks $=10$ line thicknesses, etc.). Line segments connecting areas with rabid skunk locations received a 1.5 line thickness. Sizes of line segments (e.g., length and thickness) were selected to reflect the overall rabid skunks' capture locations as well as the primary and secondary habitats.

\section{RESULTS}

\section{Rabid Animals}

The IC was observed on August 15, 1988 wandering erratically in a backyard during daylight, east of the confluence of Sage and Polecat Creeks (Fig. 1). Of 1,015 skunks tested by the WSVL for rabies, 215 (21\%) obtained at 144 trap locations (Fig. 1) were rabid (Table 1). Rabies was not confirmed in other trapped wildlife such as foxes (Vulpes vulpes), porcupines (Erethizon dorsatum), raccoons, and coyotes (Canis latrans), except for four bats (Vespertilionidae). Rabies was confirmed in one dog and one quarter horse during the 6-year epizootic.

Table 1. Number of Striped Skunks and Other Mammals Identified as Rabid by the Wyoming State Veterinary Laboratory During the Shoshone River Epizootic, 1988-1993.

\begin{tabular}{lccll}
\hline Year & $\begin{array}{c}\text { Rabid } \\
\text { skunks }\end{array}$ & $\begin{array}{l}\text { Skunks } \\
\text { processed }\end{array}$ & Bat rabies & $\begin{array}{l}\text { Domestic } \\
\text { animals }\end{array}$ \\
\hline 1988 & 1 & 1 & 0 & 0 \\
1989 & 36 & 173 & 2 & 0 \\
1990 & 39 & 114 & 0 & 0 \\
1991 & 75 & 337 & 0 & 0 \\
1992 & 60 & 207 & 2 & 1 horse \\
1993 & 4 & 183 & 0 & 1 dog \\
1994 & 0 & 0 & 0 & 0 \\
1995 & 0 & 0 & 0 & 0 \\
Total & 215 & 1,015 & 4 & 2 \\
\hline
\end{tabular}

\section{Multivariate Movement Maps}

Figure 2a-j illustrates rabid skunk epizootic location patterns using one-half year groupings. Viewing these maps in temporal sequence served to clearly indicate the directional flow of the epizootic's path. During the first 6-months of 1989, the epizootic's wave presented four leading edges: one west on Polecat Creek, one north on Sage Creek, one near Bighorn Lake, and one on the Shoshone River just east of Byron. The single crest was located just southwest of the IC (Fig. 2a). During the second half of 1989, one leading edge was south of Powell and the other remained at Bighorn Lake. The single crest was $2 \mathrm{~km}$ southwest of the confluence of Sage Creek with the Shoshone River (Fig. 2b). During January-June 1990, the epizootic continued to produce new leading edges: one northwest on Sage Creek near the Montana border and one south of Powell. The crest was $4 \mathrm{~km}$ southwest from its previous position on the Shoshone River (Fig. 2c). During the second half of 1990, substantially fewer rabid skunks were caught and no new outlier locations were recorded. One small crest was centered near the confluence east of its earlier location (Fig. 2d).

During the study's second half, many traps were placed along the Shoshone River's tributaries, irrigation ditches, and canals in response to citizen reports of skunks exhibiting unusual behavior. Few traps remained around Sage and Polecat Creeks near the IC, partly due to a substantial decrease in skunk sign and tracks. During January-June of 1991, the two leading edges and two crests nearly overlapped (Fig. 2e). During the second half of 1991, the eastern leading edge and crest remained at Bighorn Lake. The western leading edge was at Cody and the crest was south of Powell (Fig. 2f). During JanuaryJune of 1992 rabies covered nearly the entire lower SRB from Cody to Bighorn Lake. The eastern leading edge without a crest remained at Bighorn Lake. The western leading edge was southwest of Cody and a single large crest occurred near Heart Mountain (i.e., Eaglenest, Buck, and Iron Creeks), resulting in part from increased citizen daylight sightings and an associated increase of traps and captures of rabid skunks (Fig. 2g). During the second half of 1992 (Fig. 2h), a few rabid skunks were caught near Heart Mountain, while some were caught near the location of the IC. During this time, few skunks were reported by citizens and few were caught, resulting in no discernible crest(s). Three rabid skunks were caught during the first 6-months of 1993 (Fig. 2i), and the last recorded 

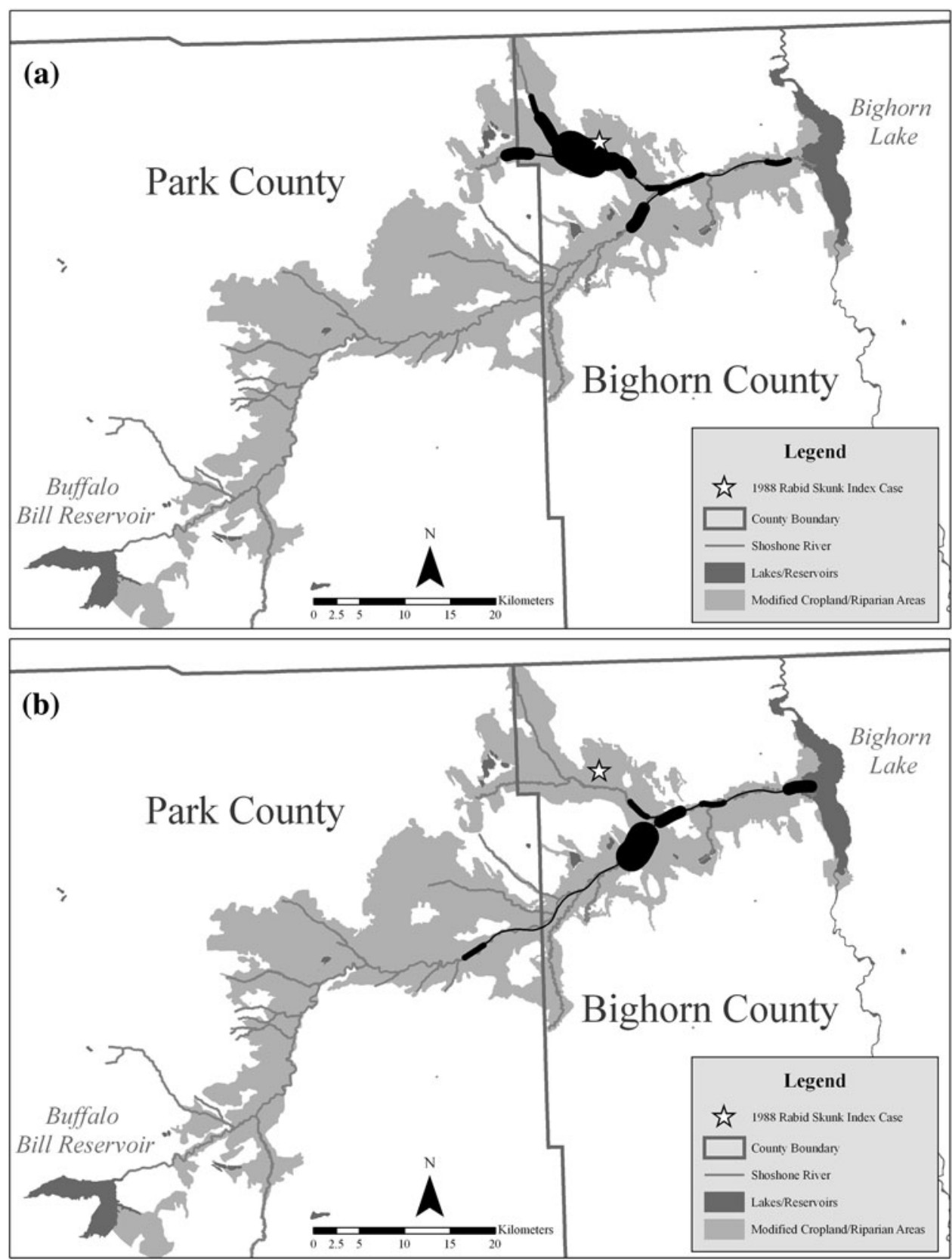

Figure 2. The SRB striped skunk rabies epizootic movements illustrated with MMMs that analyze each 6-month interval (January-June and July-December) for the entire epizootic from the Index Case (star) in 1988-1993: a January-June 1989, b July-

rabid skunk was captured north of Deaver $2 \mathrm{~km}$ from the IC (Fig. 2j).

\section{Discussion}

Surveillance data are not considered reliable for estimating rabies prevalence (Rakowski and Andrews 1972; Carey et al.
December 1989, c January-June 1990, d July-December 1990, e January-June 1991, f July-December 1991, g January-June 1992, h July-December 1992, i January-June 1993, and j July-December 1993.

1978), but they are useful in sylvatic rabies research (Macdonald and Voigt 1985), especially for identifying epizootic trends and patterns (Gremillion-Smith and Woolf 1988). Such was particularly the case for our study which appears to be the first rabies epizootic in a previously rabies-free zone monitored from the beginning to the end of the epizootic. 


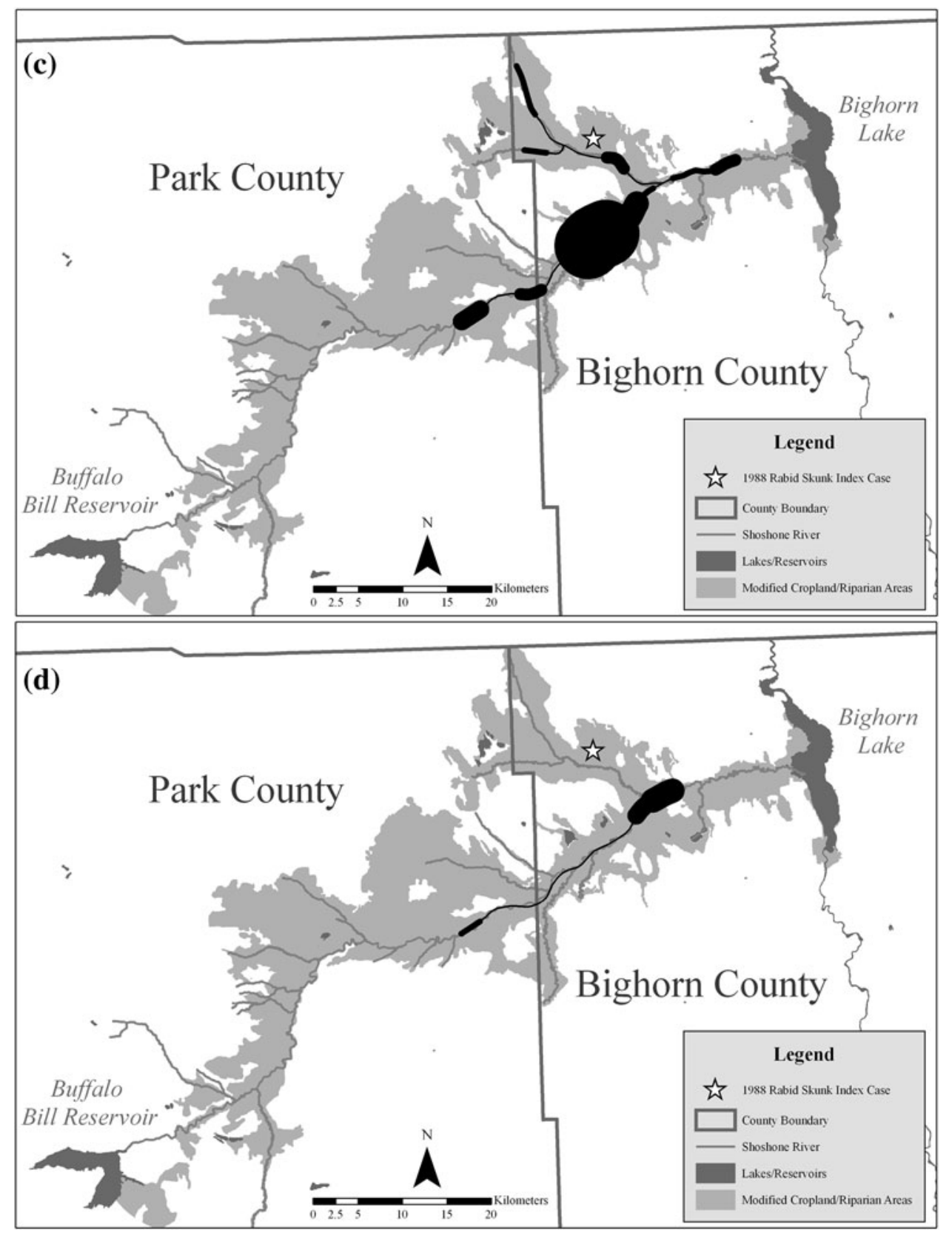

Figure 2. continued

The MMMs proved useful constructs for understanding spatial and temporal patterns of the epizootic. The method demonstrated both the leading edge(s) and especially crest densities in the epizootic wave(s). Thus, one obvious application of MMM crests would be for determining pre-crest sites to place man-made barriers, such as in a vaccination program (Ramey et al. 2009). A drawback of MMMs was that both outlier and crest locations were shown within a $2.5 \mathrm{~km}$ baseline segment and not a specific location, but these could never be known with certainty in real time unless new cases could be observed as they occurred.

Radial spreading was limited by the amount of skunk habitat, with most rabid skunk capture locations occurring near the Shoshone River, its major creeks, and irrigated farm and pasture lands (Fig. 1). Although Fig. 1 shows the extensive SRB area, much of it was arid habitat consisting mainly of sand and gravel benches, with these steep areas having water only during winter snowfalls, spring runoffs, and shortduration summer thunderstorms. Therefore, we increased our 

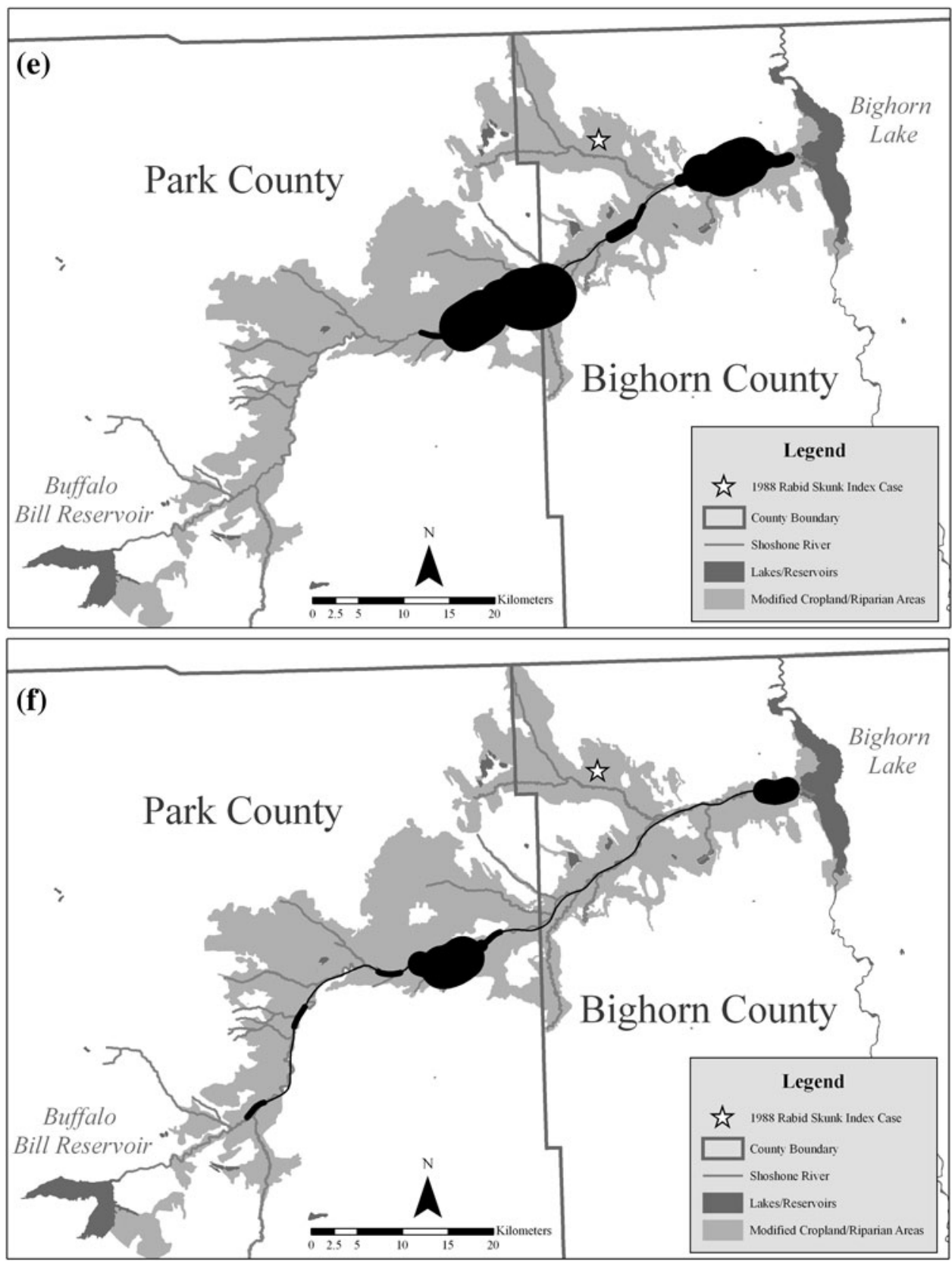

Figure 2. continued

insights by viewing habitats (Fig. 1) and hydrology (Fig. 1) together. This figure demonstrated potential barrier sites that could have been used to limit or stop the spread of the rabies during the epizootic, allowing one to imagine potentially positive results if a skunk rabies vaccine had been available and applied during the initial phases of the epizootic.

The SRB rabies epizootic's movements seemed analogous to the two wave traits discussed above. A fluid wave characteristic not observed was that of secondary waves, tertiary waves, and so on. No recognizable secondary wave occurred, probably because this rabies variant's virulence combined with depopulation by trapping reduced the skunk population behind the wave to levels that hindered skunk-toskunk rabies transmission. The density dependence of skunk rabies transmission during an epizootic was documented in Alberta (Rosatte et al. 1986), and to this point, the lower SRB has remained generally rabies-free since 1993 (i.e., 3 cases in 20 years).

Although rabies spilling into other mammalian host species is common (Smith 1986), particularly during 

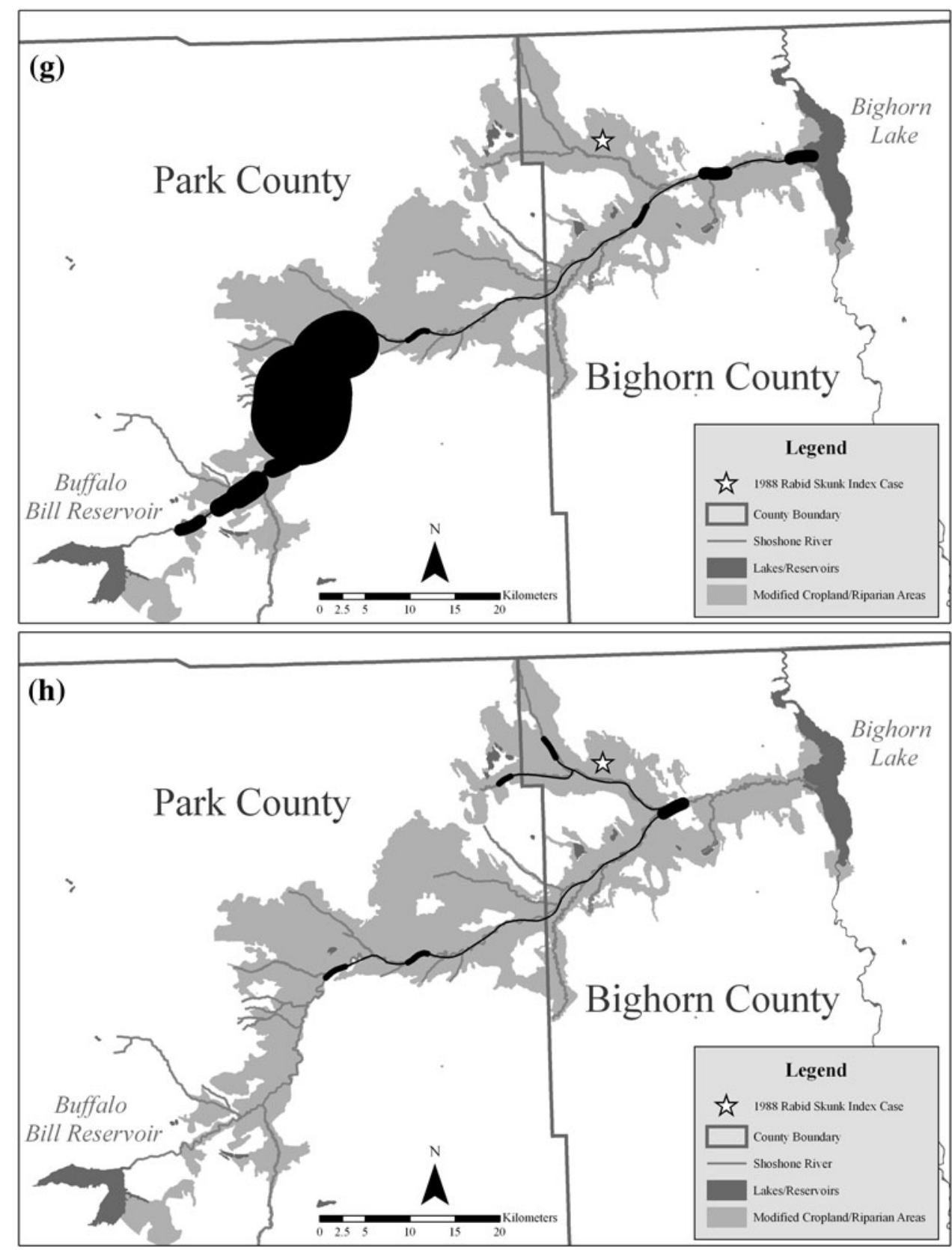

Figure 2. continued

regional epizootics (Gremillion-Smith and Woolf 1988), it was especially limited during this epizootic, probably due to species specificity of this rabies variant and vaccination programs for dogs and cats.

Unless resources are unlimited, in-field trapping of skunks for surveillance and mapping of an epizootic requires optimization of trap effort (trap quantity and placement) according to locations where positive cases were confirmed, where citizen reported suspicious animals, and the amount of potential skunk habitat showing skunk sign. For a smaller scale, methods such as passive tracking plots (Engeman et al. 2003) have been used to monitor suburban skunk population abundance to indicate promising places to trap. This methodology had not been developed for skunks at the time of the SRB epizootic, so we do not have documentation on its applicability to the SRB and whether it might have made trapping more efficient at the scale of the SRB. 


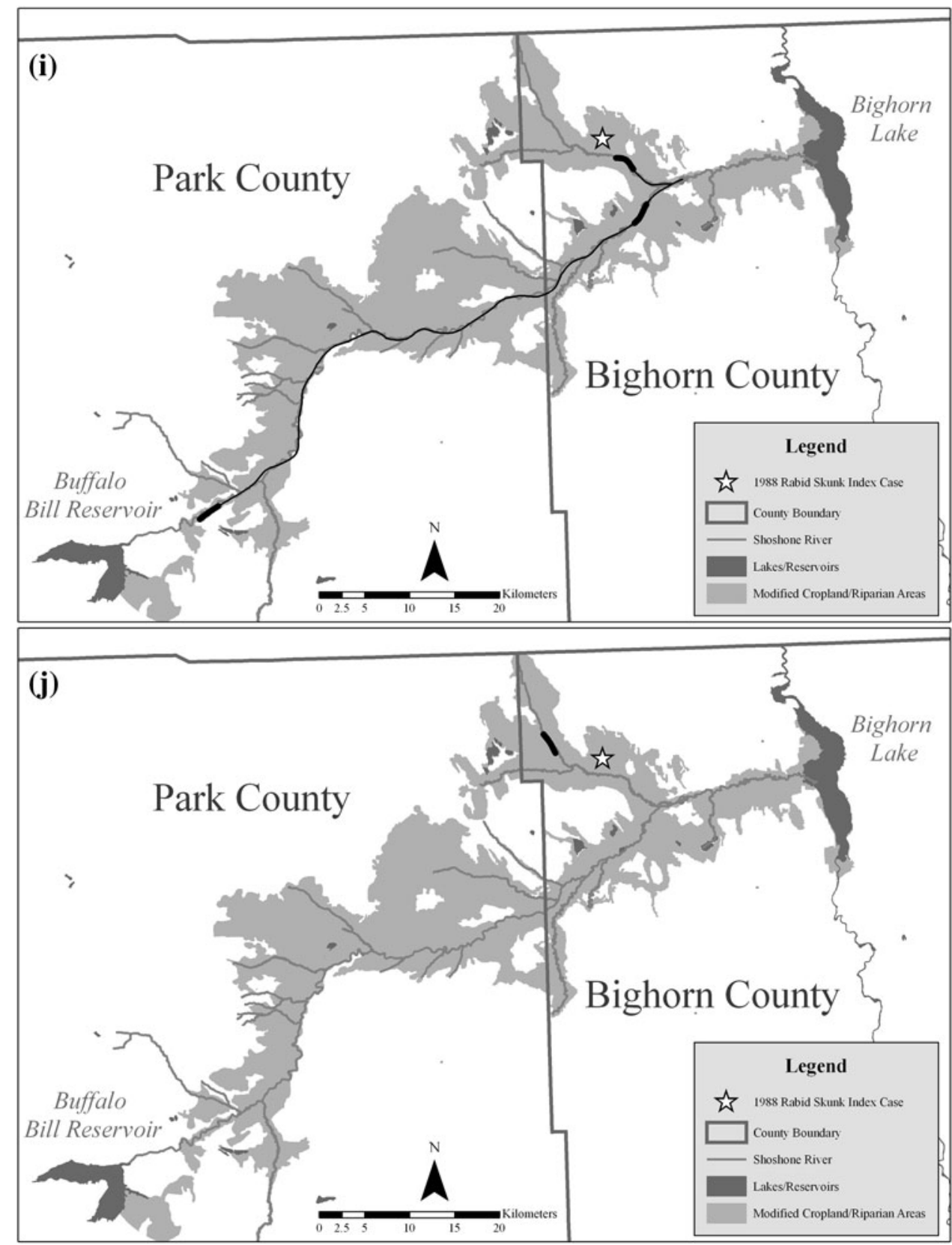

Figure 2. continued

\section{Conclusions/Management Implications}

Our investigation was aided by the epizootic's concise duration (i.e., 1988-1993), isolated floodplain location, and the decision to proactively test all potential wildlife vectors for rabies: skunks, fox, raccoons, coyotes, and bats. Our increased understanding of epizootic movement patterns inform on the etiology of rabies in specific vectors and in the potential prediction of disease occurrence, which is useful for determining control strategies. For example, the identification of epizootic fronts may be a means to spatially and temporally limit the size of vaccination programs for fox and raccoon rabies for economic and safety reasons. Vaccinating hosts in front of the wave might create a manmade barrier to continued disease spread while vaccinating behind the epizootic wave might limit enzootic foci. These actions, along with reducing vector numbers to a level incapable of sustaining continued disease spread, probably are useful first steps in controlling epizootics. Also, learning more about the functionality of enzootic foci (Gremillion-Smith 
and Woolf 1988) or the etiology of rabies variants in different reservoirs may improve control or eradication strategies. Although skunk rabies vaccine was not available, the SRB rabies epizootic demonstrated the need and could have provided an opportunity to test the usefulness of a skunk rabies vaccine.

Had MMM figures been available during the epizootic, they may have decreased the public's anxiety by providing more information of epizootic locations. This information would have been useful in predicting the epizootic's movements by allowing concurrent views of: (1) the actual rabies locations, (2) physiographic and habitat characteristics of the valley, (3) land use, and (4) and the current epizootic wave(s) with its leading edge(s) and crest(s). A GIS-based real-time mapping tool displaying instantaneous rabies surveillance on the internet (Blanton et al. 2006), combined with our epizootic wave analyses, would have been most useful in providing relevant information to the public in a rapid manner.

\section{ACKNOWLEDGMENTS}

We thank the Wyoming Department of Agriculture and Big Horn and Park counties for funding assistance and data location and verification. We sincerely thank the Wyoming State Veterinary Laboratory for the many hours spent analyzing $>1,100$ animals referred for rabies testing. We appreciate Wyoming Wildlife Services for their personal support, personnel, and funding. We acknowledge support and funding from the Pocatello Supply Depot. We thank the WS trappers for many hours spent in the field and providing their data. Also, we appreciate the Doctors of Veterinarian Medicine practicing in the Shoshone River Basin for their assistance.

\section{REFERENCES}

Baer GM (1975) The Natural History of Rabies, 1st ed., New York: Academic Press

Bagne M (1992) Rabies "hot spots" at Heart Mountain. Cody Enterprise, May 13; Sect. A:1 and A:3

Blanton JD, Manangan A, Manangan J, Hanlon CA, Slate D, Rupprecht CE (2006) Development of a GIS-based, real-time Internet mapping tool for rabies surveillance. International Journal of Health Geographics 5:47

Bonner RE (2002) Buffalo Bill Cody and Wyoming water politics. Western Historical Quarterly 33(4):433-452
Carey AB, Giles RH Jr, Mclean RG (1978) The landscape epidemiology of rabies in Virginia. American Journal of Tropical Medicine and Hygiene 27(3):573-580

Centers for Disease Control (1985) Rabies surveillance annual summary 1985 (1988). Atlanta, GA: U S Department of Health and Human Services, Public Health Service

Cloudwalker C (1991) Federal agency testing gas to kill rabid skunks. Wyoming Star. Nov 5, Sect. B-1

Dean DJ, Abelseth MK (1973) Laboratory techniques in rabies: the fluorescent antibody test. Monograph Series. World Health Organization 23:73-84

Engeman RM, Christensen KL, Pipas MJ, Bergman DL (2003) Population monitoring in support of a rabies vaccination program for skunks in Arizona. Journal of Wildlife Diseases 39:746-750

Gremillion-Smith C, Woolf A (1988) Epizootiology of skunk rabies in North America. Journal Wildlife Diseases 24(4):620-626

Hanlon CA, Childs JE, Nettles VF (1999) Recommendations of a national working group on prevention and control of rabies in the United States. Article III: Rabies in wildlife. Journal of the American Veterinary Medical Association 5(11):1612-1619

Jeltsch F, Muller MS, Grimm V, Wissel C, Brandl R (1997) Pattern formation triggered by rare events: lessons from the spread of rabies. Proceedings of the Royal Society of London. Series B: Biological Sciences 264(1381):495-503

Kallen A, Arcuri P, Murray JD (1985) A simple model for the spread and control of rabies. Journal of Theoretical Biology 116(3):377393

Macdonald DW, Voigt DR (1985) The biological basis of rabies models. In: Population Dynamics of Rabies in Wildlife, Bacon PJ (editor), New York: Academic Press, pp 71-108

McLean RG (1970) Wildlife rabies in the United States: recent history and current concepts. Journal Wildlife Diseases 6:229235

McQueen JL, Lewis AL, Schneider NJ (1960) Rabies diagnosis by fluorescent antibody. I. Its evaluation in a public health laboratory. American Journal of Public Health 50:1743-1752

Parker RL (1975) Rabies in skunks. In: The Natural History of Rabies, Baer GM (editor), New York: Academic Press, pp 41-51

Rakowski PW, Andrews MF (1972) The geographic distribution of skunk rabies in North Dakota. Proceedings of the North Dakota Academy of Science 25:65-71

Ramey CA (1992) Product performance with the coyote gas cartridge (EPA Reg. No. 56228-21) in a field efficacy study with the striped skunk (Mephitis mephitis). Denver (CO): Denver Wildlife Research Center QA-203 report, pp 1-195

Ramey CA, Dickerson LD, Robin MW (1994) Wave-like epizootic of striped skunk rabies in northwestern Wyoming. In: Abstracts, 43rd Annual Conference of the Wildlife Disease Association, July 17-22, Monterey, CA. No. 39, pp 44-45

Ramey CA, Mills KH, Robin MW (2007) Overview of the first use of GPS 1991/GIS 1992 during a Wyoming skunk rabies epizootic. In: Proceedings of the 12th Wildlife Damage Management Conference, Apr 9-12, Nolte DL, Arjo WM, Stalman D (editors), Corpus Christi, TX, pp 245-252

Ramey CA, Mills KH, Robin MW (2008) Synopsis of the Shoshone River skunk rabies epizootic in northwestern Wyoming. In: Proceedings of the 23rd Vertebrate Pest Conference, Mar 17-20, Timm RM, Madon MB (editors), San Diego, CA, pp 259-263 
Ramey CA, Mills KH, Fischer JW, McLean RG (2009) Retrospective barriers for a skunk rabies epizootic in NW Wyoming. In: Proceedings of the 13th Wildlife Damage Management Conference, May 4-6, Boulanger J (editor), Saratoga Springs, NY, pp 263-264

Ramey CA, Mills KH, Fischer JW (2010) Evolving analyses of the Shoshone River skunk rabies epizootic in Wyoming. In: Proceedings of the 24th Vertebrate Pest Conference, Feb 22-25, Timm RM, Fagerstone KA (editors), Sacramento, CA, pp 322-332

Ramey CA, Mills KH, Fischer JW, McLean RG (2011) Didactic lessons derived from the Shoshone River skunk rabies epizootic. In: Proceedings of the 14th Wildlife Damage Management Conference, Apr 18-21, Frey SN (editor), Nebraska City, NE, pp 6473

Ritter DF (1975) New information concerning the geomorphic evolution of the Bighorn Basin. In: Wyoming Geological Association 27th Annual Field Conference Guidebook, Sept 8-9, Cody, WY, pp 37-44

Rosatte RC, Phybus MJ, Gunson JR (1986) Population reduction as a factor in the control of skunk rabies in Alberta. Journal Wildlife Diseases 22:459-467

Rupprecht CE, Smith JS, Fekadu M, Childs JE (1995) The ascension of wildlife rabies: a cause for public health concern or intervention? Emerging Infectious Diseases 1(4):107-114

Shwiff SA, Sterner RT, Jay-Russell M, Parikh S, Bellomy A, Meltzer MI, Rupprecht CE, Slate D (2007) Direct and indirect cost of rabies exposure: a retrospective study in Southern California (1998-2002). Journal Wildlife Diseases 43:251-257
Sikes R (1981) Rabies. In: Infectious Diseases of Wild Mammals, Davis JW, Karstad LH, Trainer DO (editors), Ames, IA: Iowa State University Press, pp 3-17

Smith JS (1986) Rabies virus epitopic variation: use in ecological studies. Advances in Virus Research 36:215-253

Smith DL, Lucey B, Waller LA, Childs JE, Real LA (2002) Predicting the spatial dynamics of rabies epidemics on heterogeneous landscapes. Proceedings of the National Academy of Sciences of the United States of America 99(6):36683672

Thorne ET, McLean RG (1982) Viruses. In: Diseases of Wildlife in Wyoming, Thorne ET, Kingston N, Jolley WR, Bergstrom RC (editors), Cheyenne, WY: Wyoming Game and Fish Department, pp 1-27

Tufte ER (1983) The Visual Display of Quantitative Information, 1st ed., Cheshire, CT: Graphics Press

U.S. Department of Agriculture/Animal and Plant Health Inspection Service, U.S. Department of Agriculture/Forest Service and Department of Interior/Bureau of Land Management (1997) Animal Damage Control Program Final Environmental Impact Statement (Revised), Washington, DC: USDA/Animal and Plant Health Inspection Service

Winkler WG (1975) Fox rabies. In: The Natural History of Rabies, Baer GM (editor), New York: Academic Press, pp 3-22 